\title{
Pozitif Psikolojik Sermayenin Yenilikçi Davranış Üzerindeki Etkisi: Bankacılık Sektöründe Bir Araştırma
}

\section{The Influence of Positive Psychological Capital on Innovative Behavior: A Research in the Banking Sector}

\author{
Edip Örücü a, Binnaz Çınar ${ }^{\text {b,* }}$
}

a Prof. Dr., Bandırma Onyedi Eylül Üniversitesi, İktisadi ve İdari Bilimler Fakültesi, İşletme Bölümü, Balıkesir/Türkiye. ORCID: 0000-0002-3301-7496

${ }^{\text {b }}$ Doktora Öğrencisi, Bandırma Onyedi Eylül Üniversitesi, Sosyal Bilimler Enstitüsü, İşletme Bölümü, Balıkesir/Türkiye. ORCID: 0000-0002-0323-9864

\section{MAKALE BİLGİSI}

Makale Geçmişi:

Başvuru tarihi: 16 Ağustos 2018

Düzeltme tarihi: 02 Kasım 2018

Kabul tarihi: 05 Aralık 2018

\section{Anahtar Kelimeler:}

Pozitif Psikolojik Sermaye

Yenilikçi Davranış

Bankacılık Sektörü

\section{ARTICLE INFO}

Article history:

Received 16 August 2018

Received in revised form 02 November 2018 Accepted 05 December 2018

\section{Keywords:}

Positive Psychological Capital

Innovative Behavior

Banking Sector

\section{ÖZ}

\begin{abstract}
Bu çalışmanın temel amacı, bankacılık sektöründe görev alan çalışanların pozitif psikolojik sermaye (özyeterlilik, umut, psikolojik dayanıklılık ve iyimserlik) düzeylerinin yenilikçi davranışları üzerinde etkilerinin olup olmadığının incelenmesidir. Bu amaca ulaşmak için, veriler Balıkesir'in Bandırma ilçesinde görev alan banka çalışanlarından kolayda örnekleme ve anket yöntemi kullanılarak toplanmıştır. 125 anket dikkate alınarak analizler gerçekleştirilmiştir. Araştırma sonucu regresyon analizinde, pozitif psikolojik sermaye alt boyutlarından psikolojik dayanıklılığın yenilikçi davranışı anlamlı bir şekilde etkilediği saptanmıştır. Bununla birlikte, pozitif psikolojik sermaye alt boyutları özyeterlilik, umut ve iyimserlik düzeylerinin yenilikçi davranış üzerinde etkili olmadığı belirlenmiştir.
\end{abstract}

\section{A B S T R A C T}

The main purpose of this study is to examine whether the employees in the banking sector have positive psychological capital (self-efficacy, hope, psychological resilience and optimism) levels on their innovative behaviors. In order to achieve this aim, data were collected from the bank employees in the Bandırma district of Balıkesir by using sampling and survey method. A total of 125 questionnaires were analyzed. In the regression analysis, found that psychological resilience from the subscales of positive psychological capital has positive affect on the innovative behavior. In addition, positive psychological capital subscales self-efficacy, hope and optimism has not effect on innovative behavior.

\section{Giriş}

Örgütlerde pozitif ve güçlü yönlere odaklanmak, örgüt stratejileri geliştirilmesi ve rekabet avantajı sağlanması açısından önem kazanan bir olgu haline gelmiştir. Doğru kullanılan insan kaynağı, pozitif psikoloji akımının son y1llarda gelişmesiyle birlikte örgütlerin büyük gücü olarak ifade edilmektedir. Örgütlerin sahip olduğu insan kaynağının rekabet üstünlüğünü ortaya çıkartarak kullanabilmeleri, bu kaynağa büyük yatırımlar yapmalarını gerektirmektedir. Bu durumu ortaya çıkaran bilim insanları, pozitif psikolojik sermaye olgusunu ifade etmeye başlamışlardır (Yeşil, Yetiş ve Telli, 2016: 23). Pozitif örgütsel davranış alanında gerçekleştirilen araştırmalar sonucu, örgütlerde çalışanın değerinin anlaşılması ve bunula birlikte çalışan potansiyelini ortaya koymak için sosyal ve insan sermayelerin dişında psikolojik sermaye olgusu değerli olmaya başlamıştır (Luthans ve Youssef, 2004; Luthans, Youssef ve Avolio, 2006). Psikolojik sermaye; ölçülebilen, geliştirilebilen ve çalışanların performanslarındaki artışa etken olarak yönlendirilen ve çalışanların psikolojik kapasiteleri ve güçlü yönlerini ele alan pozitif psikolojik süreçlerini ifade etmektedir (Luthans, 2002a). Pozitif psikolojik sermaye,

\footnotetext{
* Sorumlu yazar/Corresponding author.

e-posta: binnazcinar62@gmail.com
} 
pozitif örgütsel davranış algıları ile aynı sonuçlara sahip olarak, örgüt içerisinde pozitif sonuçlar ortaya çıkarmaktadır.

Örgüt içerisindeki başarının sağlanabilmesi, sadece fiziksel ve finansal sermayenin oluşmasıyla yeterli olmamaktadır. Ancak çalışanın performansı, kuruma bağlılığı, işine duyduğu olumlu hissi, motivasyonu, iş tatmini, gelecekten beklentileri, yenilikçi davranışlara açık olması örgütsel başarıyı sağlayacaktır. Bunun için de, çalışanın psikolojik durumunun iyileştirilmesi, kapasite ve yeteneklerinin ortaya çıkartılması için firsatlar oluşturulmalı ve çalışanların yetenekleri eğitimler ile geliştirilmelidir. Çalışanların, iş hayatı yanında sosyal çevresi ve aile yaşamından kaynaklanan ve kendi üzerinde meydana gelen negatif ve pozitif duyguların, iş hayatında sergilediği performansı etkileyebileceği göz ardı edilmemelidir (Aydoğan ve Kara, 2015: 69).

Rekabetin günden güne daha şiddetli bir hal aldığg ve ihtiyaçların hızlı bir şekilde değiştiği günümüz koşullarında, işletmelerin yaşamlarını sürdürebilmesinde yeniliğin önemli bir rolü bulunmaktadır. Çalışanların yenilikle ortaya çıkabilecek yeni fikirlerini sergileyebilmeleri açısından yenilikçi davranışa yönelik algıları da önem taşımaktadır. Çalışanların yenilikçi davranışı rekabet üstünlüğünü sürdürmesini sağlayacaktır. $\mathrm{Bu}$ sebeple günümüz örgütlerince yatırımların ve stratejilerin gerçekleştirilmesi için yenilikçilik önemli bir kaynaktır. Ayrıca, yöneticilere ve insan kaynakları departmanlarında görev alan çalışanlara yönelik politikalara değer katacağı öngörülmektedir.

Çalışanların psikolojik davranışları olarak tanımlanan özyeterlilik, umut, psikolojik dayanıklllı ve iyimserlik psikolojik sermaye düzeyinin boyutlarl şeklinde irdelenmektedir (Luthans, Avolio, Walumbwa ve Weixing, 2005; Luthans, Avolio, Avey ve Norman, 2007; Sweetman, Luthans, Avey ve Luthans, 2011). Bu alt boyutların, örgüt çalışanının çalışma hayatının önemli olduğu varsayılarak, büyük bir rol oynayacağı düşünülmektedir. Başka bir ifadeyle; yeteneklerine güvenmeyen, hedeflere ulaşılabilmede dayanıklılık ve motivasyon sağlayamayan ve sonucunda ileriye yönelik pozitif beklenti içinde olmayan bireyin işletmeye nasıl katkı vereceği, rekabet durumuna ne kadar ayak uydurabileceği, iş hayatı ile ilgili sorunlara nasıl çözümler üreteceği ve verimlilik konusunda nasıl bir performans sergileyeceği bilinmemektedir. Örgüt çalışanlarının sahip oldukları pozitif psikolojik sermayenin, örgüt içerisinde sergiledikleri yenilikçi davranışlara etkilerini ortaya koymaktadır. Bu çerçevede, yerli ve yabancı yazında, çalışanların pozitif psikolojik sermayelerinin yenilikçi davranışlara etkilerinin yer aldığ dikkate alınmıştır (Bandura, 1977; Luthans vd., 2004; Avey, Luthans ve Youssef, 2009; Whelan, Parise, Valk ve Aalbers, 2011; Ertürk, 2012; Beğenirbaş ve Turgut, 2016; Karadal ve Özsungur, 2017). Bu kapsamda incelenen yazın taraması ile birlikte araştırma kapsamı belirlenmiş ve bu çalışma ortaya çıkarılmıştır. $\mathrm{Bu}$ çalışmanın amacı banka sektöründe çalışanların, pozitif psikolojik sermaye düzeylerine yönelik algılarının yenilikçi davranış üzerindeki etkilerini belirlemektir. Literatürdeki çalışmalar irdelendiğinde, bankacılık sektöründe bu konuyu ele alan araştırmaya pek rastlanmamış olmakla birlikte, bu ifade çalışmamızın önemini ortaya koymakta ve gelecekteki araştırmalara yarar sağlayacağı düşünülmektedir. Bu araştırmadan elde edilecek bulguların pozitif psikolojik sermaye ve yenilikçi davranış literatürüne önemli katkılar sağlayacağı söylenebilir.

\section{Kavramsal Çerçeve}

\subsection{Pozitif Psikolojik Sermaye}

Yabancı yazında "PsyCap" olarak ifade edilen "pozitif psikolojik sermaye" kavramı (Luthans vd., 2004; Luthans vd., 2007), pozitif psikoloji teorisi ve araştırmalarından faydalanmaktadır (Luthans, Norman, Avolio ve Avey, 2008'den aktaran: Kızanlıklı ve Çöp, 2017). Pozitif psikoloji, hayat standartlarını geliştirecek, kişiler tarafından anlamsızlaştığında ve yararlı olmadığı algılandığında ortaya çıkacak patolojik rahatsılıkları engelleyecek, pozitif öznel tecrübeleri ve pozitif kişilik özelliklerini irdeleyen bir alanı kapsamaktadır. Pozitif psikolojinin alanı; "memnuniyet, tatmin ve iyi olma" geçmiş zamanda; "iyimserlik ve umut" gelecek zamanda; "sağlık ve mutluluk" şimdiki zamanda birlikte anlamlı duyguları ifade etmektedir. Pozitif psikolojinin; bireylerin cesaret, sevgi kapasitesi, ileri görüşlülük, estetik duygusu, yetenek, azim, kişilerarası ilişkiler, özgünlük, yetenek, moral gibi olumlu kişisel özellikleriyle alakalı olduğu bilinmektedir (Seligman ve Csikszentmihalyi, 2000: 6).

Pozitif psikoloji, hümanistik psikoloji açısından ilk defa 1960'l1 y1llarda Abraham H. Maslow ve arkadaşları Carl Rogers ve Erich Fromm tarafinca ortaya çıkarılmıştır (Karacaoğlu ve İnce, 2013: 183). Fakat 1998'li yıllara gelindiğinde ünlü psikolog M. Seligman'a göre insanların güçlü yanlarını, potansiyelleri ve yeteneklerinin farkına varabilmeleri ve bunları kazandirabilmek amaciyla meydana çıkan pozitif psikoloji, örgütsel davranış alanına önemli bir katkı sağlamıştır. Mikro açıdan ise Luthans (2002b), işletmelerde çalışan performansının artırılması için çalışanların psikolojik kapasitelerinin ve güçlü yanlarının durağan değil, geliştirilebilir olduğunu belirtmektedir. Bu dönemde meydana çıkarılan ve geliştirilen pozitif psikolojinin etkisi ile beraber, örgütsel davranış alanına pozitif bir bakışın gerekliliğini ifade etmektedir. Bu sebeple, Luthans (2002b) pozitif psikolojik örgütsel davranış kavramının önemini vurgulamıştır. Pozitif örgütsel davranış, "örgüt içerisindeki performansı artırmak amacıyla çalışanların psikolojik kapasitesi ve güçlü yönleri üzerindeki uygulama ve çalışmalar" olarak ifade edilmektedir (Luthans, 2002b).

Psikolojik sermaye, ne bildiğinizi açıklayan insan sermayesinden, neye sahip olduğunuzu açıklayan ekonomik sermayeden, kimi tanıdığınızı açıklayan sosyal sermayeden farklı olarak "ne olduğunuz, kim olduğunuz ve ne olmaya niyetlendiğinizi" ifade etmektedir (Avolio ve Luthans, 2006: 147). Böylece pozitif örgütsel davranış, çalışanların zayıf yönleri yerine, güçlü taraflarını ortaya koyma ve güçlü tarafların ardındaki psikolojik unsurları ölçme, geliştirme ve yönetme yoluyla örgüt içerisinde performansta iyileşmeleri amaçlayan bir yaklaşım olarak irdelenmektedir (Luthans, 2002a; Luthans 2002b; Lewis, 2011: 142). Bununla birlikte, psikolojik sermayenin örgüt içerisindeki işlerle ilgili davranış ve düşünceleri geliştirdiği ve hayata bakış açısını olumlu yönde etkilediği belirtilmektedir (Luthans vd., 2007). Pozitif psikolojik sermaye, pozitif örgütsel davranış kıstaslarını toparlayan ve bütünleştiren yapıya sahiptir. Bu nedenle, psikolojik sermayenin bütün boyutları arasında 
ilişki olduğu savunulmaktadır. Örneğin; umutlu insanlar, zorlukların üstesinden gelebilmek için güdülenmekte ve dolayısıyla daha fazla direnç göstermektedirler. Özyeterlilikleri yüksek olan bireyler; psikolojik dayanırlıklarını, iyimserliklerini ve umutlarını kolaylıkla yaşamlarına adapte edebilir ve uygulayabilirler (Luthans vd., 2006: 19-20). Pozitif psikolojik sermayenin, pozitif örgütsel davranışın ölçülebilir performansla, olumlu, eşsiz olmasıyla ilgili kriterlerine cevap veren; özyeterlilik, umut, psikolojik dayanıklılık ve iyimserlik gibi bazı temel boyutları bulunmaktadır (Luthans vd., 2004).

\subsection{1. Özyeterlilik}

Özyeterlilik kavramı, Bandura (1997) tarafından Sosyal Bilişsel Teorisine (Sosyal Öğrenme Teoriye) dayandırılan ve pozitif psikolojik sermaye boyutları arasında gelişime açık olması, araştırma ve teoriye dayalı olması ve performans üzerindeki etkisi onaylanması sebebiyle pozitif örgütsel davranış kriterlerine cevap veren bir kavram olarak literatürde yer almaktadır (Luthans, 2010: 234). Özyeterlilik örgüt içinde çalışanların, örgüt tarafından ulaşılması gereken amaçlara yönelik ihtiyaç duydukları motivasyonları belirlemek için yeteneklerine olan inanç ve güven özyeterliliklerini tanımlamaktadır (Stajkovic ve Luthans, 1998: 66-67; Luthans vd., 2006; Harms ve Luthans, 2012: 590). Diğer yandan Bandura (1986) özyeterliliği, bireyin hedeflere ulaşabilmesi için davranışları ortaya çıkarma ve uygulayabilmede sahip olduğu kabiliyetlerine güvenmesi olarak ifade etmektedir. $\mathrm{Bu}$ yönden irdelendiğinde özyeterlilik; kişinin belirli bir alanda, bir görevi başarılı olarak uygulayabilmesinde gerekliliğini hissettiği motivasyon, olaylar ve bilişsel süreçleri ortaya çıkarmak için kendine olan inancıdır.

Kişinin belli bir görevde özyeterlilik sahibi olması; o görevi başarıyla gerçekleştirmesi, başkalarının deneyiminden faydalanması, onlar tarafından teşvik edilmesi ve kendisine pozitif geribildirimde bulunmasıdır (Akçay, 2012: 125). Özyeterliliği yüksek olan çalışanlar, diğer kişilerin onlar için belirlediği amaçları beklemez, aksine sürekli olarak daha fazla hedef belirleyip, zor görevler karşısında istekliliklerini ortaya koyarlar (Luthans vd., 2007). Bu durumda, özyeterlilikleri düşük düzeydeki çalışanların pes ettikleri gözlemlenirken, yüksek düzeyde özyeterliliğe sahip çalışanların daha fazla gayret göstererek işlerinde başarılı oldukları gözlemlenmiştir (Robbins, 2001: 167).

\subsubsection{Umut}

Psikolojik sermayenin ikinci bir diğer önemli boyutu olan "umut"u, ilk kez C. Rick Synder pozitif psikoloji araştırmalarıyla yazına kazandırmıştır. Umut, kişilerin başarı duygusuna yönelik pozitif bir motivasyon durumu olup, kişinin başarı duygusu ve belirlediği hedeflere ulaşması aşamasında, gösterdiği amaç ve kararlılık ile birlikte bu hedeflere geçiş yaparken kullanabileceği alternatif yöntemlerin belirlenmesi olarak yazında yer almaktadır (Jensen ve Luthans, 2006). Bu açıdan incelendiğinde umut boyutu, kişinin ulaşabileceği amaçların belirlenmesi değil, bununla birlikte amaçlara ulaşabilme yönteminin belirlenmesi ve bu yöntemle ilerleyebilmek için kendi motivasyonunu sağlayabilmesidir.
Umut bileşeni ile ilgili araştırmalar gerçekleştiren Jerome Frank (1968) umut ifadesini, "iyi olma duygusu veren ve kişiyi harekete geçirmek için güdüleyen bir özellik” şeklinde tanımlamaktadır (Frank, 1968'den aktaran: Akman ve Korkut, 1993: 193). Keleş (2011: 348), umudun iş hayatında, çalışan kişilerde işe başlarken motivasyonu arttıran ve yüksek performans sağlayan bir nitelik taşıdığını belirtmektedir. Türkmenoğlu (2018), umudun zorluklar karşısında işletme yöneticileri için önemli bir baş etme mekanizması olduğunu ifade etmektedir. İşletmelerde güçlendirme, karar alma, yetki artırma ve iletişim kurma gibi bir iş ortamı elde etmeye odaklı yollar çalışanların daha güçlü, özgür karar almalarına, böylece hedefe ulaşabilmede çeşitli yöntemler geliştirmelerine katkı sağlamaktadır (Akçay, 2012: 126).

\subsubsection{Psikolojik Dayanıklılık}

Pozitif psikolojik sermaye bileşenlerinden psikolojik dayanıklılık, kişinin birtakım pozitif ve negatif koşullar içerisinde sergilediği pozitif durum ya da bu koşulları karşılama gücüdür (Luthans, 2002b). Bir başka ifadeyle, bireyin karşılaştığı tüm zorluklara (risk, negatif durumlar ve engel) karşı uyumunu, dayanma gücünü, değişiklikler karşısında tepkilerini ve esnekliğini ifade etmektedir (Masten, 2001: 235). Maddi (2006: 180)'a göre psikolojik dayanıklılık; örgüt içinde çalışanların belirsizlik, anlaşmazlık, terslik ve başarısızlık gibi durumlarda kendilerini iyileştirme ve toparlamaları için katkı verirken stresin azaltılmasıyla olaylarla mücadele edebilme yeteneğini doğrulayan birey özelliğini kapsamaktadır. Stresle başa çıkabilmenin yanında, başarı sağlayabilmek için gerekli olan psikolojik dayanıklılığın özünde psikolojik sağlamlık yatmaktadır.

Psikologlar tarafından dayanıklılık süreci, faktörlerin etkili bir şekilde rol oynayıp oynamadığının belirlenmesidir (Luthar, Cicchetti ve Becker, 2000: 552). Psikolojik dayanıklılığın çeşitli risk durumlarında korunmasızlık ve koruyucu güçlerin farklılaşan dengesini kapsayan bir süreç olduğu ifade edilmektedir. Dayanıklılık kavramı altı faktörden oluşmaktadır. Bunlar; gelecek algısı, benlik algısı, sosyal yeterlilik, yapısal stil, sosyal kaynaklar ve aile uyumudur (Çetin ve Basım, 2012: 126). Bunlara dayanarak psikolojik dayanıklılık zor olan görevler karşısında üstünlüğü sağlayabilmek için güvene sahip olma, şu anda ve gelecek zamanda başarı sergileneceğine dair olumlu beklenti, başarının sürekliliğini sağlamak için sorunların üstesinden gelebilme, bireyin pozitif psikolojik durumunun göstergesidir (Erkmen ve Esen, 2013: 24).

\subsubsection{Iyimserlik}

Pozitif psikolojik sermayenin alt bileşenlerinden olan iyimserlik kavramının geçmişi, psikolog M. Seligman'a (1998) aittir. Seligman (1998)'ın çalışmaları neticesiyle, pozitif psikolojik sermaye alt boyutları ile iyimserlik karşılaştırıldığında iyimserliğin, pozitif psikoloji ile yakından ilişki bir kavram olduğu görülmektedir (Seligman, 1998'den aktaran: K1zanlıklı vd., 2017: 268). İyimserlik, şimdi ve gelecekte başarmayı sağlayacak pozitif bir beklentiyi ve objektif değerlendirmeleri kapsamaktadır (Luthans vd., 2004; Luthans vd., 2008). Bunun dışında, Seligman (2002)'in yüklem teorisinden faydalanan iyimserlik tanımlaması, bireylerin kötü ve iyi durumları 
belirleyebilme durumunda, önemli iki faktör şeklinde açıklanan "istikrar" ve "yayılma" kavramlarını ortaya çıkarmaktadır. Dolayısıyla kötümser bireyler kötü durumları kalıcı olarak yorumlayabilirken, iyimser bireyler olayların kalıcı olmadığını görmektedirler (Luthans vd., 2004). İyimserlik, iş ortamında çalışanların başarısız ve başarılı olabilmelerinde kaynak ve yeteneklerinin daha düzgün ve doğru uygulanabilmesine, amaçlarına ulaşılabilmesine katkı sağlamaktadır (Luthans vd., 2007).

\subsection{Yenilikçi Davranış}

Yenilikçilik kavramı, Drucker (1985), Dess ve Lumpkin (2005), Damanpour ve Evan (1984) tarafindan kavramın farklı özellikleriyle tanımlanmaktadır. Çelik (2012: 102), yeni ürün veya hizmetlerin, yeni pazarların, yeni örgütsel şekillerin ve yeni tedarik kaynaklarının bulunmasıyla birlikte geliştirilmesi olarak tanımlamaktadır. Woodman, Sawyer ve Griffin (1993)'e göre yenilikçilik, işletme içerisinde yeni ürünlerin müşteriye sunulması, çalışma şartları altında yeniliklerin ortaya çıkarılarak uygulamaya geçilmesi olarak ifade edilirken; yenilikçi davranış, çalışanların mevcut yenilik isteyerek ve gönüllü olarak kabullenmeleri ve bunları görevlerinde gerçekleştirerek işletmenin tamamına yansitmalarıdır (West ve Farr, 1986; Yuan ve Woddman, 2012).

Yenilikçi davranış, problemlerin nelerden kaynaklandığı, yenilikçi fikir ve çözüm seçeneklerinin ortaya çıkarılması, deneyimlenmesi üretim ve hizmetlerde kullanılmasını içeren birden çok aşamadan oluşmaktadır (Scott ve Bruce, 1994). Yenilikçi davranış örgütlerde rekabeti artıran stratejik bir etkinlik olarak algılanması ve çalışanlara yönlendirilmesi, çalışma yöntemlerini hayata geçirmede, hedeflere ulaşmada yeni alternatiflerin önerilmesi ve yeni kaynakların araştırılmasıyla, yaratıcı ve yeni fikirleri uygulamada ve davranışlar üzerinde sergilemelerini gerekli kılmaktadır (Yuan ve Woddman, 2010; Wu, Parker ve Jong, 2014). Bu bağlamda yenilikçi davranış ile çok karıştırılan ve ara sıra da birbirlerinin yerine kullanılabilen yaratıcılık kavramı ile yenilikçiliği birbirinden ayırt etmek gerekmektedir (Unsworth, Brown ve McGuire, 2000). Yaratıcılık ve yenilikçi davranışların birbirlerine yakınlığı bulunmasına rağmen yaratıcılık, yeni buluşların ve fikirlerin meydana çıkarılması olarak ifade edilmektedir. Yenilikçi davranış ise yeni fikir ve düşüncelerin oluşturulmasıyla birlikte, bu fikir ve düşüncelerin işletme içerisinde adaptasyonunu sağlanarak, işletme faydası için uygulanıp kullanılmasıdır (Zhou, 2003).

Örgütler arasındaki rekabetin yoğun bir şekilde yaşandığı son zamanlarda, işletmelerin değişim ve yenilikler üzerinde yoğunlaşarak proaktif yaklaşım ve tutum göstermeleri işletmelerin sürdürülebilirlikleri açısından önemli ve kaçınılmaz bir durumdur (Akkoç, Turunç ve Çalışkan, 2011). Günümüz iş hayatında, örgütler arasında rekabetin olması, varlıklarının devamı için yeterli olmamaktadır. Bütün örgütler, çalışanları sayesinde rekabet üstünlügünü elde etme ve fark yaratma peşindedir. Dolayısıyla, yenilikçilik kavramı rekabet avantajını ortaya çıkaran en önemli faktörlerden biri olarak kabul edilmektedir (Lumpkin ve Dess, 2001; Hayton ve Kelley, 2006).

İşletmelerin yenilikçi bir yapıya sahip olmaları, çalışanlarının yenilikçi davranışlar gösterebilmesine bağlıdır
(Sanders, Moorkamp, Torka, Groenveld ve Groeneveld, 2010). İşletme içerisinde yer alan yenilikçilik, Kanter (1988)'e göre üç aşamalı karmaşık davranışların oluşmasıyla meydana gelmektedir. Birinci aşamada, kişi sorunların farkına varmakta ve bu sorunlarla ilgili yeni çözüm önerileri ortaya çıkarmalıdır. İkinci safhada, yenilik fikrini yaratan kişi, bulduğu fikirleri ve çözüm önerilerini destekleyecek işletme içi ve dışında destekler aramaktadır. Son safhada ise, yenilikçi davranış sergileyen kişi, çözümün işletme içinde uygulanıp denenmesi için yeni modeller üreterek fikri maddi boyuta taşımaktadır (Carmeli, Meitar ve Weisberg, 2006).

\section{Literatürde Yapılan Çalışmalar}

\subsection{Pozitif Psikolojik Sermaye ve Alt Boyutları ile İlgili Çalışmalar}

Pozitif psikolojik sermayenin, pek çok araştırma konusu içerisinde araştırmacilar tarafindan incelendiği görülmektedir. İncelenen her bir çalışmanın farklı sektörler üzerinde yapıldığı ve bununla birlikte farklı sonuçlar elde edildiği gözlemlenmiştir.

Luthans vd. (2007)'ın pozitif psikolojik sermaye ve iş tatmini arasındaki ilişki irdelenmiş ve hizmet ve sanayi kurumları arasından seçilen iki değişik veri seti üzerinde analizler yapılmıştır. Söz konusu Sanayi kurumlarında; psikolojik sermaye alt boyutları olan umut ve öz yeterlilik ile iş tatmini arasında pozitif ve anlamlı bir ilişki bulunurken, psikolojik sermayenin diğer alt boyutları olan dayanıklılık ve iyimserlik ile iş tatmini arasında herhangi bir ilişki tespit edilememiştir. Hizmet işletmelerinde ise; özyeterlilik, iyimserlik ve umut alt boyutlarıyla iş tatmini arasında anlamlı bir ilişki bulunurken, dayanıklılık ile iş tatmini arasında bir ilişkinin olmadığ belirlenmiştir.

Keleş (2011), psikolojik sermaye kavramının açıklanması, bileşenleri ve işletme yönetimi üzerindeki etkileri üzerine bir araştırma yapmıştır. Bu araştırmanın amacı, Türk literatürü için gelecekte gerçekleşecek araştırma konuları arasındaki yerini almasıdır. $\mathrm{Bu}$ amaca yönelik, bu çalışmada, uluslararası alanda son zamanlarda daha fazla çalışmada yer alan pozitif psikolojik sermaye kavramı ve boyutları açıklanarak, işletme yönetimine olan etkileri irdelenmiştir.

Yıldız ve Örücü (2016) ise, sağlık sektöründe görev alan bireyleri demografik faktörler bakımından psikolojik sermayenin belirlenmesi amacıyla bir araştırma yapmıştır. Ístanbul'da 7 kamu hastanesinden A gustos-Aralık 2014 arasında 1141 sağlık çalışanı üzerinden anket yöntemi ile veri toplanmıştır. Çalışanların psikolojik sermaye düzeyi ile demografik faktörler (yaş, statü, eğitim, deneyim ve çalışma süresi) arasında, farklılık olduğu tespit edilmiştir.

Kızanlıklı vd., (2017) tarafından otel işletmeleri çalışanları üzerinde psikolojik sermaye ile iş performansı algısı arasındaki ilişkiyi irdelemiştir. İstanbul'da faaliyette olan 5 yıldızlı otellerde görev alan 280 veri ile analizler yapılmıştır. Araştırma sonucuna göre, psikolojik sermaye düzeyinin iş performansı üzerindeki etkisi, psikolojik sermaye boyutlarından fazla bir etkide bulunduğu saptanmıştır.

Avey, Reichard, Luthans ve Mhatre (2011), pozitif psikolojik sermayenin çalışan tutumları, davranışları ile performansları üzerindeki etkisini incelemek için nicel bir analiz yapmıştır. Araştırma kapsamında 12.567 katılımcıya 
dayanan 51 bağımsız örnek belirlenip, bunlardan 15 'i dergi makalesi, 2'si henüz basılmamış tez, 28'i ise yeni veya henüz yayınlanmamış çalışma verilerinden oluşmaktadır. Çalışmada pozitif psikolojik sermayenin çalışan tutumları (iş doyumu, örgütsel bağlılık), çalıșan davranışları (vatandaşlık) ve performans (benlik) üzerinde anlamlı bir etkiye sahip olduğu belirlenmiştir.

Jung ve Yoon (2015) tarafindan deluxe oteller görev alan 324 çalışan üzerinde pozitif psikolojik sermaye (dayanıklılık, umut, özyeterlilik ve iyimserlik) ile örgütsel vatandaşlık ve iş tatmini arasındaki ilişkinin ortaya çıkarılması amaçlanmıştır. Araştırma sonucunda pozitif psikolojik sermaye alt boyutlarından umut ve iyimserliğin iş tatminini, umut boyutunun örgütsel vatandaşlığı güçlü bir şekilde etkilediği belirlenmiştir.

Hur, Rhee ve Ahn (2016) ise, Güney Kore'deki en büyük havayolu şirketinde çalışan 236 uçuş görevlisi üzerinde veriler toplayarak, örgütsel adalet algısı ve pozitif pozitif psikolojik sermaye ile ilgili bir çalışma yapmıştır. Algılanan dağıtım ve prosedür adaletin hizmet çalışanlarının psikolojik sermayesi ile ilişkisi olduğu çalışma bulgularında ortaya çıkmıştır.

Pozitif psikolojik sermayenin liderlik ile örgütsel bağlılık arasında aracı rolünü incelemek için Rego, Lopes ve Nascimento (2016)'da bir çalışma yapmıştır. Bu nicel araştırmada liderlik ve örgütsel bağlılık arasındaki ilişkiyi yönlendiren pozitif psikolojik sermayenin dört boyutu (iyimserlik, umut, dayanıklılık ve özyeterlilik) üzerine bir model sunulmuştur. Araştırma sonuçları arasında pozitif psikolojik sermayenin liderlik ve örgütsel bağlılık arasındaki ilişkiye aracılık ettiği yer almaktadır. Fakat aracı etkide pozitif psikolojik sermaye alt boyutlarından iyimserlik, özyeterlilik ve umudun pozitif etkilediği, dayanıklılığın ise negatif etkilediği tespit edilmiştir.

Grobler ve Joubert (2018) araştırmasında psikolojik sermaye anketi çok faktörlü bir model istatistik olarak araştırılmış ve doğrulanmıştır. Güney Afrika'daki 30 kuruluştan her biri 60 kişi olmak üzere 1749 katılımcı araştırma örneklemini oluşturmaktadır. Araştırma sonucunda pozitif psikolojik sermayenin kavramsallaştırılması ampirik olarak doğrulanmış ve umut, iyimserlik, özyeterlilik ve dayanıklılık olmak üzere dört boyut ile desteklenmiştir.

\subsection{Yenilikçi Davranış İle İlgili Çalışmalar}

Çalışkan vd. (2011) motivasyonel davranışların, örgütsel performansın artırılması hususundaki etkilerini saptamak amacıyla bir araştırma yapmıştır. Ayrıca, yenilikçi ve girişimci davranışların bu etkiye aracılık edip etmediği incelenmiştir. Savunma sektöründe çalışan 302 çalışan üzerinde gerçekleştirilen araştırmada değişkenler yapısal eşitlik modeli ile analiz edilmiştir. Analiz neticesinde, motivasyonel davranışların örgütsel performansı artırdığı ve yenilikçi ve girişimci davranışlarda aracılık etkisinin bulunduğu saptanmıştır.

Çelik (2012), işletmeler arasındaki rekabet avantajı sağlamada işletmelere katkı sağlayan yenilikçi davranışların meydana gelmesinde, çalışanların adalet algılarının rolünün incelenmesi ve kariyer memnuniyetlerinin aracilık rolünün ortaya çıkarılması çalışmanın sorunsalını oluşturmaktadır. Antalya'da yer alan küçük ölçekli otel işletmelerinde görev alan 260 kişi üzerinde anket toplanmıștır ve çalıșanların adalet algılarının yenilikçi davranışlar ve kariyer memnuniyetleri üzerindeki etkisi ortaya çıkarılmıştır. Gerçekleştirilen analizler neticesinde, kariyer memnuniyetinin dağıtım adaleti ve yenilikçi davranış arasında tam, diğer iki boyut (prosedür ve etkileşim) ile yenilikçi davranışlar arasında kısmi aracılık etkisinin olduğu belirlenmiştir.

Turgut ve Beğenirbaş (2013), hastanelerdeki sosyal sermaye ve yenilikçi iklimin yenilikçi davranışa etkisini belirlemek için bir çalışma yapılmıştır. Bu amaçla, Kütahya'da bulunan özel ve kamu hastanelerinde 398 çalışan üzerinde yapılan anket ile veriler sağlanmıştır. Araştırmada ölçekler yapısal eşitlik modeli ile test edilmiştir. Araştırma bulgularında yapusal sosyal sermaye ve bilişsel sosyal sermayenin yenilikçi iklim boyutları ve yenilikçi davranıs üzerinde etkisi bulunamamıştır. İlişkisel sosyal sermayenin yenilikçi iklim boyutlarını ve yenilikçi davranışı güçlü ve pozitif etkilediği belirlenmiştir.

Clercq, Dimov ve Belausteguigoitia (2016), çalışanların olumsuz çalışma koşullarına ilişkin yenilikçi davranış rollerini açıklamaya yönelik bir araştırma yapmıştır. Meksika'da faaliyette bulunan bir kuruluştan alınan veriler analiz edilmiş ve çalışanların işyerinde yaşadıkları olumsuz koşulların (iş yükü fazlalıklarının) yenilikçi davranışlarını olumsuz etkilediği ortaya çıkmıştır. Ayrıca olumsuz iş koşullarının yer aldığ 1 kuruluşlarda, iş stresinin azaltılabilmesi için ilgili kanalların yenilikçi fikirleri desteklemesi gerektiği ifade edilmektedir.

Melhem, Zeffane ve Albaity (2018), çalışanların yenilikçi davranışlarının belirleyicilerinin neler olduğu, işyerindeki mutluluğunun, iş arkadaşlarının desteğinin ve iş stresinin çalışanların yenilikçi davranışlarına olan etkisini ve iş arkadaşlarının destek ve iş stresinin aracı etkileri çalışma kapsamında araştırılmıștır. Birleşik Arap Emirlikleri'nde dört ve beş yıldızlı otellerde farklı departmanlarda çalışan 328 çalışan örneklemi oluşturmaktadır. İşyeri memnuniyeti, çalışanların yenilikçi davranışlarının en önemli belirleyicisi olurken, iş arkadaşlarının desteği önemli bir aracı rol oynamaktadır. Araştırmada iş stresinin tek başına önemli bir arabulucu olmadığı, iş arkadaşlarının desteğiyle birleştirildiğinde sadece aracı rol oynadığı sonucuna ulaşılmıştır.

Hrnjic, Velic, Djidelija ve Jahic (2018) araştırmalarında insan kaynakları yönetimi uygulamalarının yenilik sürecinde etkinliğini inceleyerek, iş tatminin, telekomünikasyon sektöründe yenilikçi kapasite geliştirme üzerindeki etkisini araştırmayı amaçlanmıştır. Araştırma örneklemini telekomünikasyon sektöründe çalışan 116 çalışan oluşturmaktadır. İş tatmininin çalışanların yenilikçi davranışları ve iş görevlerindeki iyileşme üzerinde olumlu bir etkiye sahip olduğu sonucuna ulaşılmıştır.

Chou, Huang ve Lin (2018) çalışmanın ilk amacını örgütsel entelektüel sermayenin üç boyutunun (insan sermayesi, örgütsel sermaye ve müşteri sermayesi) ön büro hizmeti çalışanlarının yenilikçi davranışlarına olan etkileri oluşturmaktadır. Çalışmanın diğer amacı ise, değer yaratma davranışının (tüketici gönüllü davranışına odaklanarak) örgütsel entelektüel sermayenin boyutlarının ön büro hizmeti çalışanlarının yenilikçi davranışları üzerindeki etkisini belirlemektir. Tayvan Taipei'de bulunan bir seyahat 
acentesinde çalıșan ön büro çalışanlarından toplam 282 geçerli anket toplanmış ve örneklem oluşturulmuştur. Güvenilirlik ve geçerlilik analizi ve keşif faktörü analizi, ortak yöntem varyans testi ve yapısal denklem modellemesi çalışma kapsamında kullanılmıştır. İnsan sermayesi ve müşteri sermayesi, ön büro hizmeti çalışanlarının yenilikçi davranışlarını olumlu yönde etkilediği sonucuna ulaşılmıştır. Değer yaratma ile müşteri sermayesi arasındaki etkileşimler, ön büro çalışanı için yenilikçi davranışları önemli ölçüde etkilediği araştırmanın diğer sonuçları arasında yer almaktadir.

Engelen, Weinekötter, Saeed ve Enke (2018)'da yaptıkları çalışmada kurumsal destek programlarının çalışanların yenilikçi davranışlarına etkisini kültürlerarası olarak araştırılmıştır. Araştırma, iki adet bağımsız çalışmadan oluşmaktadır. İlk çalışma 2011 Küresel Girişimcilik İzlemi özel raporundaki ikincil verileri kullanmaktadır. 13 ülkede 11.560 tam zamanlı çalışandan alınan yanıtlar yer almaktadır ve ikinci aşamada Almanya ve Çin'de çalışanların bireysel davranışları kullanarak deneysel çalışma yürütülmüştür. İlk araştırmanın sonuçları, ülkenin güç mesafesi ve erkek oranının düşük ve bireycilik güçlü olduğunda, destek ve yenilikçi davranış arasındaki ilişkinin daha olumlu olduğunu göstermektedir. İkinci çalışmada da üç tür kurumsal destek programının, çalışanların Almanya'daki örnekleminde yenilikçi davranışlarını olumlu etkilediğini, ancak Çin'deki örneklem grubunda anlamlı bir ilişkinin olmadığı sonucuna varılmıştır.

\subsection{Pozitif Psikolojik Sermaye ve Yenilikçi Davranış İle İlgili Çalışmalar}

İşletmelerin büyümeleri, etkinlik, verimlilik ve pazar payını elde edebilmesi yolunda bireysel odaklı çalışanların işletmeye fayda getirecek yenilikçi davranışlar sergilemeleri işletme açısından büyük bir önem arz etmektedir (Avey ve Nimnicht, 2010). Çalışanlar dışında işletmelerin de yenilikçi davranışları benimsemesi performanslarını artıracak ve bununla birlikte daha uzun süre sürdürülebilirliklerini koruyacaktır (Erdem, Gökdeniz ve Met, 2011).

Pozitif psikolojik sermayenin çalışanların yenilikçi davranışlarına doğrudan etkileri ulusal literatür araştırmalarında çok fazla rastlanmamasına rağmen, uluslararası literatürde de sınırlı sayıda yer verildiği gözlemlenmiştir. $\mathrm{Bu}$ araştırmalar genelinde yenilik ve yenilikçi davranışın yetenek, yeterlilik ve bilgi yanında, özyeterlilik (Bandura, 1977; Robbins, 2001; Luthans vd., 2004; Harms vd., 2012), iyimserlik, umut ve psikolojik dayanıklılık (Masten, 2001; Luthans vd., 2004; Whelan, Parise, Valk ve Aalbers, 2011) kapsamında yer alan psikolojik sermayeden pozitif ve anlamlı bir şekilde etkilendiği belirlenmiştir. Çalışanların aldıkları psikolojik destek neticesinde, psikolojik sermayelerinin artırılma çabalarının, çalışanların yenilikçi düzeylerini artırarak, yenilikçi davranışlar gösterebilmelerine sebep olduğu saptanmıştır (Ertürk, 2012). Bununla birlikte, Luthans, Avey, Avolio ve Peterson (2010) tarafından çalışanların pozitif psikolojik sermayeleri ile yenilikçi davranış arasındaki ilişkiyi pozitif duygularla açıklanabilmektedir.

Basım, Korkmazyürek ve Tokat (2008) kamu kurum ve kuruluşlarında çalışan 230 kişinin özyeterlilik algıları ile yenilikçi davranışları değerlendirilmiştir. Kullanılan değişkenler arasındaki ilişkiler t-testi ile incelenmiștir. Araştırma sonuçları arasında çalışanların özyeterlilik algılarının mevcut ortalamanın üzerinde olduğu tespit edilmiştir. Yenilikçi davranışın ise yüksek seviyede olduğunu saptanmıştır. Bununla birlikte, özyeterlilik algısı ile yenilikçilik davranıșları arasında bir ilișkiye rastlanılmamıştır.

Abbas ve Raja (2015) gerçekleştirdikleri araştırmada pozitif psikolojik sermayenin yenilikçi davranış ve iş stresi arasındaki ilişki incelenmiştir. Pakistan'da çeşitli kuruluşlarda çalışan 237 kişi üzerinden veriler toplanmıştır. Pozitif psikolojik sermayenin iş performansıyla pozitif ilişkisi olduğu ve iş stresiyle negatif ilişkisi olduğu belirlenmiştir. Yüksek pozitif psikolojik sermaye düzeyine sahip çalışanların daha yenilikçi davranışlar sergiledikleri araştırma sonuçları arasında yer almaktadır. Özellikle yüksek pozitif psikolojik sermaye düzeyine sahip çalışanların, işyerinde yeni fikirler üretme, yöneticilerden destek alma ve yeni fikirlerin uygulanma olasılığının daha fazla olduğu ortaya çıkmıştır. Aynı zamanda yüksek psikolojik sermayeye sahip çalışanların, düşük pozitif psikolojik sermayeye sahip çalışma arkadaşlarıyla karşılaştırıldığında düşük iş stresine sahip oldukları belirlenmiştir.

Beğenirbaş ve Turgut (2016), çalışanların içinde bulunduğu psikolojilerinin işe karşı davranışlarında, yeni fikirler elde ederek performanslarının artmasında önemli bir rol oynayacağı belirtilmektedir. Bu amaçla, Ankara'da yer alan kamu ve özel savunma sektöründe çalışan 189 kişiden elde edilen verilerden yararlanılmıştır. Araştırma bulgularında psikolojik sermaye boyutlarının iş performansı ile yenilikçi davranıș üzerinde pozitif etkili olduğu sonucuna ulaşılmıștır. Bununla birlikte, araştırmaya katılanların yenilikçi davranışlarının psikolojik sermaye boyutları ve iş performansları arasında anlamlı bir aracı rolü saptanmamıştır.

Karadal ve Özsungur (2017) tarafından yenilikçi davranış, etik liderlik ve psikolojik sermaye arasındaki ilişki incelenmiştir. Çalışma örneklemini Adana'da üretim alanında faaliyet gösteren ticari işletmelerden rastgele seçim yöntemiyle 317 çalışan oluşturmaktadır. Korelasyon analiz sonuçlarına göre, yenilikçi davranış ve psikolojik sermaye ile etik liderlik arasında anlamlı bir ilişkinin varlığından söz edilmektedir.

Özkan (2017), araştırmasında çalışanların özyeterlik düzeylerinin yaratıcı ve yenilikçi çalışma davranışlarına etkisini belirlemek amaciyla irdelemiştir. $\mathrm{Bu}$ amaç doğrultusunda finans, perakende, havacilık ve enerji çalışanlarının özyeterlik, yenilikçi iş davranışları anket araştırması ile değerlendirilmiştir. Araştırma bulgularında, çalışanların özyeterlik düzeylerinin, yenilikçi iş davranışları üzerinde olumlu bir etkiye sahip olduğu sonucuna ulaşılmıştır. Ancak, özyeterliliğin yaratıcı iş davranışları üzerinde yenilikçi iş davranışlarından daha büyük bir etkisinin olduğu belirlenmiștir. Buna ek olarak, havacılık ve enerji sektörlerindeki çalışanların, perakende ve finans sektöründeki çalışanlara göre, havacılık çalışanlarının perakende ve finans çalışanlarından daha fazla yenilikçi davranış sergilediği çalışanlardan daha yaratıcı olduklarını ortaya koymaktadır. Ayrıca, özyeterlik ile sektör arasındaki yaratıcı ve yenilikçi çalışma davranışları arasındaki etkileşim etkisi anlamlı bulunmamıştır. 
Jafri (2012) tarafindan gerçekleştirilen araştırmada, Hindistan'daki giyim modası endüstrisi çalışanları üzerindeki psikolojik sermayenin yenilikçi davranış üzerindeki ilişsi ve etkisi araştırılmıştır. Veriler, Delhi'de farklı moda evlerinde farklı seviyelerde çalışan 130 çalışandan toplanmıştır. Katılımcılar kartopu örneklemesine göre seçilmiştir. Pozitif psikolojik sermaye için Luthans vd., (2007)'nın ölçeği ve yenilikçi davranış için de İshak (2005) tarafından geliştirilen ölçek kullanılmıştır. Araştırma sonucunda, her iki değişkenin de ilişkili olduğunu ve psikolojik sermayenin çalışanın yenilikçi davranışı önemli ölçüde etkilediği tespit edilmiştir.

Ziyae, Mobaraki ve Saeediyoun (2015), İran'ın Tahran'da faaliyet gösteren Tarım Bankası şubeleri arasında Bilişim Teknolojisinde psikolojik sermayenin inovasyon üzerindeki etkisi incelenmiştir. Araştırmanın örneklemini, Tahran'daki Tarım banka şubelerinde çalışan 132 yönetici ve çalışanı içermektedir. $\mathrm{Bu}$ kişiler arasından Cochran formülü kullanılarak ve rasgele örnekleme yöntemiyle 100 kişi seçilmiştir. Çalışmanın sonuçları arasında, psikolojik sermayenin Bilişim Teknolojisindeki yenilikler üzerinde önemli bir etkisi olduğu belirlenmiştir. Ayrıca, psikolojik sermaye boyutlarının (özyeterlilik, umut, iyimserlik, dayanıklılık) dayanıklılık dışında hiçbirinin Bilişim Teknolojisinde yeniliği geliştirmediği ortaya çıkarılmıştır.

Kim, Karatepe ve Lee (2017) araştırmalarında ise, psikolojik sözleşme ihlalinin çalışanların psikolojik sermayelerini örselediği ve yenilikçi davranışlarına mani olduğu ortaya çıkarılmıştır. Bununla birlikte psikolojik sermayenin çalışanların yenilikçi davranışlarını canlandırdığı, psikolojik sözleşme ihlalinin yenilikçi davranış için psikolojik sermayenin aracılık ettiği sonucuna ulaşılmıştır (Kim vd., 2017'den aktaran: Karadal vd., 2017: 664).

Güney Kore'nin Seul şehrinde bulunan 15 adet beş yildızlı otelde 336 tam zamanlı çalışandan farklı zaman içinde anket yöntemi ile Schuckert, Kim, Paek ve Lee (2017) tarafından veriler sağlanmıştır. $\mathrm{Bu}$ araştırmada özgün liderlik, dönüşümcü liderlik, yenilikçi davranış ile pozitif psikolojik sermaye arasındaki ilişki bir model ile test edilmiştir. Araştırma sonucunda özgün liderliğin pozitif psikolojik sermaye ve yenilikçi davranış üzerinde dönüşümcü liderlikten daha büyük etkiye sahip olduğu saptanmıştır. Pozitif psikolojik sermayenin kısmi bir aracı rolü incelenirken, özgün liderlik ve dönüşümcü liderliğin yenilikçi davranışı doğrudan izleyen hipotezler desteklenmiştir. Ayrıca pozitif psikolojik yenilikçi davranışı etkilediği sonucuna ulaşılmıştır.

Literatürde yapılan çalışmalar doğrultusunda araştırma modeli ve hipotezleri geliştirilmiştir. Modelde, "Pozitif Psikolojik Sermaye alt boyutlarl (özyeterlilik, umut, psikolojik dayanıklılık ve iyimserlik)" bağımsız değişkeni, "Yenilikçi Davranış" ise bağımlı değişkeni oluşturmaktadır. Bu kapsamda literatür incelemesi sonucunda bu çalışma için aşağıdaki hipotezler ve araştırma modeli ileri sürülmüştür:

H1:Çalışanların özyeterliliklerinin yenilikçi davranışları üzerinde anlamlı etkisi vardır.

H2:Çalışanların umut sahibi olmalarının yenilikçi davranışları üzerinde anlamlı etkisi vardır.

H3:Çalışanların psikolojik dayanıklılıklarının yenilikçi davranışları üzerinde anlamlı etkisi vardır.
H4:Çalıșanların iyimserliklerinin yenilikçi davranışları üzerinde anlamlı etkisi vardır.

Şekil 1. Araștırmanın Modeli

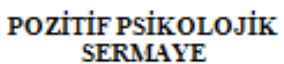

SERMAYE

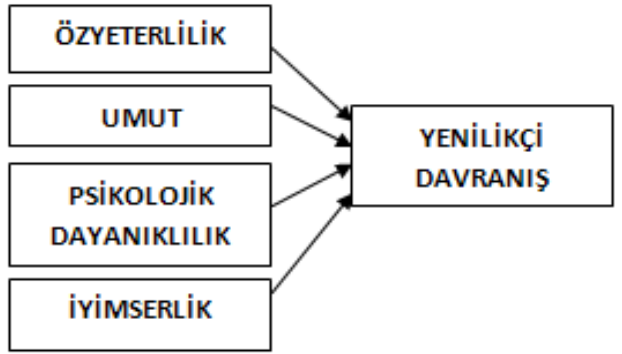

\section{Araştırma Yöntemi}

\subsection{Araștırmanın Amacı}

$\mathrm{Bu}$ araştırmanın amacı, bankacılık sektöründe görev alan çalışanların pozitif psikolojik sermaye (özyeterlilik, umut, psikolojik dayanıklılık ve iyimserlik) düzeylerinin yenilikçi davranış üzerindeki etkilerinin belirlenmesidir.

\subsection{Araştırmanın Evreni, Örneklemi ve Veri Toplama Yöntemi}

Araştırmanın evreni Bandırma ilçesinde yer alan 18 bankada çalışan sayısı yaklaşık 250 banka çalıșanı oluşturmaktadır. Bu çerçevede $\mathrm{p}$ ve $\mathrm{q}$ değerleri 0,5 ve 0,5 , hoşgörü $\mathrm{E}=0,05$ ve $\% 95$ güven aralığında 250 kişiyi $\% 95$ güven aralığında 151 kişinin temsil etme yeteneğine sahip olduğu hesaplanmıştır (Altunışık, Coşkun, Bayraktaroğlu ve Yıldırım, 2010: 135). Anket uygulaması ve kolayda örnekleme yöntemiyle 125 adet kullanılabilecek anket elde edilmiştir. Sağlanan geri dönüşler neticesinde örneklemin yaklaşık \%82'sini temsil edebildiğini göstermektedir. Verilerin toplanması Mart 2018 tarihinde gerçekleştirilmiştir.

\section{3. raştırmada Kullanılan Ölçekler}

Araştırmada kullanılan boyutların ölçülmesi maksadıyla detaylı bir literatür taraması yapılmıştır. Sağlanan ölçeklerden, uygun olduğu düşünülenler bu araştırmaya uyarlanmıştır. Çalışma amacına uygun olarak hazırlanmış anket formu giriş yazısıyla birlikte üç kısımdan oluşmaktadır. Anket formunun ikinci kısmında demografik özelliklere yer verilmiştir. Üçüncü kısmında ise, araştırmanın modelini oluşturan pozitif psikolojik sermaye ve yenilikçi davranış değişkenlerini ölçmeye dayalı sorular bulunmaktadır.

Pozitif psikolojik sermaye ölçeği (24 ifade) Luthans vd., (2007) tarafından geliştirilmiştir ve özyeterlilik (6 ifade), umut (6 ifade), iyimserlik (6 ifade) ve dayanıklılı ( 6 ifade) olmak üzere dört alt boyuttan oluşmaktadır. Araştırmada ölçeğin geçerlilik ve güvenilirliklerini inceleyen Çetin ve Basım (2012) ve Erkuş ve Afacan Fındıklı (2013: 309-310) tarafından uygulanan Türkçe hali kullanılmıștır. Pozitif psikolojik sermaye ölçeği ulusal yazında Akçay (2012), Erkmen vd., (2013), Ocak vd., (2016), Y1ldı vd., (2016) ve Karadal vd., (2017) tarafından kullanılmıştır. 
Yenilikçi davranış ölçeği Scott ve Bruce (1994) tarafından geliştirilerek 6 ifadeden oluşmaktadır. Bu araştırmada Akkoç vd. (2011) tarafindan Türkçe'ye uyarlanan yenilikçi davranış ölçeği kullanılmıştır. Yenilikçi davranış ölçeği ulusal yazında Akkoç vd. (2011), Çalışkan vd. (2011), Çelik (2012), Beğenirbaş vd. (2016) tarafindan araştırmalarda uygulanmıştır. Çalışmada kullanılan ölçekler 5'li likert ölçeğine göre düzenlenmiştir.

\section{Araştırma Bulguları}

Öncelikle demografik özelliklere yönelik sorulara ilişkin frekans analizleri yapılmıştır. Daha sonra araştırmada ölçeklerin güvenirliliği için Cronbach's Alpha katsayısı incelenmiştir.

Bir verinin normal bir dağılım gösterip göstermediği farklı yollarla tespit edilebilmektedir. Öncelikle veriye, Kolmogorov-Smirnov ( $>30)$ testi uygulanabilir. Bu test sonucunun anlamlı olmasi $(\mathrm{p}>0.05)$, verilerin normal dağıldığı anlamını ifade etmektedir. Bir başka yol ise verilerin çarpıklık ve basıklık değerlerine bakılabilir. Normal bir dağılımda bu değerlerin, +1.5 ile -1.5 arasında olması gerekmektedir. Yaygın kabul edilen bir başka anlayışa göre, çarpıklık ve basıklık değerlerinin, kendi standart hatasına bölünmesi ile elde edilen değer, 3.2'nin altında kalıyor ise o verinin normal dağıldığı varsayılmaktadır (Gürbüz ve Şahin, 2017: 214). Bu açıklama doğrultusunda yapılan analizler sonucunda Kurtosis ve Skewness oranlarının +1.5 ile -1.5 arasında ve $\mathrm{p}>0.05$ anlamlılı seviyesinde olduğundan dağılımın anlamlı ve normal olduğu belirlenmiştir [Özyeterlilik=Kurtosis ve Skewness (,430/-1,462), Umut=Kurtosis ve Skewness (-,226/-,725), Psikolojik
Dayanıl111k=Kurtosis ve Skewness (1,464/-,916), İyimserlik=Kurtosis ve Skewness $(-, 511 /-, 204)$, Yenilikçi Davranış=Kurtosis ve Skewness $(-1,324 /-, 430)]$. Modeldeki değişkenler arasındaki ilişkinin tespit edilmesi Pearson korelasyon analiziyle, aralarındaki etkileri belirlemek için ise regresyon analizi uygulanmıştır.

\subsection{Demografik Bulgular}

Araştırmaya katılanlar demografik açıdan incelendiğinde, \%34,4'ü (N=43) kadın, \%65,6'sı (N=82) erkek olduğu görülmektedir. Katılımcıların \%39,2'si ( $\mathrm{N}=49)$ bekâr ve $\% 60,8$ 'i $(\mathrm{N}=76)$ evlidir. \%9,6 ( $=12)$ oranında önlisans, $\% 66,4(\mathrm{~N}=83)$ oranında lisans ve \%24,0 ( $=30)$ oranında lisansüstü (yüksek lisans/doktora) mezunu olan katılımcıların, \%27,2'si (N=32) 24-34 yaş aralığında, \%35,2'si (N=47) 35-45 yaş aralığında, \%28'i (N=33) 46-56 yaş aralığında ve \%9,6'sı (N=13) 57 ve üzeri yaş aralığındadır. Kurumdaki çalışma süresi incelendiğinde ise, katılımcıların, \%27,2'si (N=34) 1-4 yıl, \%44'ü (N=55) 5-8 yıl arasında, \% 27,2'si (N=34) 9 yıl ve üzeri çalışma süresinin olduğu belirlenmiştir. Ayrıca, analizler incelendiğinde 2 kişinin bu soruya cevap vermediği tespit edilmiştir. Katılımcıların \%19,2'si ( $\mathrm{N}=24)$ gişe görevlisi, \%24,8'i (N=31) müşteri temsilcisi, \%39,2'si (N=49) operasyon görevlisi ve $\% 16,8^{\prime} i$ ( $\left.=21\right)$ şube müdürüdür. Ankete katılanların, \%40'1 (N=50) 1900-2699 gelire, \%36's1 (N=45) 2700-3799 gelire, \%18,4'ü $(\mathrm{N}=23)$ 3800-5499 gelire ve \%2,4'ü (N=3) 5500 ve üzeri aylık gelire sahiptir. Bununla birlikte, katılımcılardan 4 kişi bu soru hakkında herhangi bir cevap vermedikleri saptanmıştır. Katılımcıların demografik faktörlerine dair Frekans Analizi sonuçları Tablo 1'de sunulmuştur.

Tablo 1. Demografik Bulgular

\begin{tabular}{|c|c|c|c|c|c|c|c|c|}
\hline Yaş & $\mathrm{n}$ & $\%$ & Aylik Gelir & $\mathrm{n}$ & $\%$ & Bankadaki Pozisyon & $\mathrm{n}$ & $\%$ \\
\hline $24-34$ & 32 & 27,2 & $1900-2699$ & 50 & 40,0 & Gişe Görevlisi & 24 & 19,2 \\
\hline $35-45$ & 47 & 35,2 & 2700-3799 & 45 & 36,0 & Müșteri Temsilcisi & 31 & 24,8 \\
\hline $46-56$ & 33 & 28,0 & $3800-5499$ & 23 & 18,4 & Operasyon Görevlisi & 49 & 39,2 \\
\hline 57 ve üzeri & 13 & 9,6 & 5500 ve üzeri & 3 & 2,4 & Şube Yöneticisi & 21 & 16,8 \\
\hline Eğitim Durum & $\mathrm{n}$ & $\%$ & Banka Çalışma süresi & $\mathrm{n}$ & $\%$ & & & \\
\hline Önlisans & 12 & 9,6 & $1-4 \mathrm{y} 1 \mathrm{l}$ & 34 & 27,2 & & & \\
\hline Lisans & 83 & 66,4 & $5-8$ y1l & 55 & 44,0 & & & \\
\hline L.üstü & 30 & 24,0 & 9 ve üzeri & 34 & 27,2 & & & \\
\hline Medeni Durum & $\mathrm{n}$ & $\%$ & Cinsiyet & $\mathrm{n}$ & $\%$ & & & \\
\hline Evli & 76 & 60,8 & Kadin & 43 & 34.4 & & & \\
\hline Bekâr & 49 & 39,2 & Erkek & 82 & 65.6 & & & \\
\hline
\end{tabular}

Pozitif psikolojik sermaye ortalaması 3,864, yenilikçi davranış ortalaması ise 4,093 olarak saptanmıştır. Yenilikçi davranış ölçeği ortalamasının, pozitif psikolojik sermaye ölçeği ortalamasından yüksek olduğu belirlenmiştir. Pozitif psikolojik sermaye alt boyutlarında ise, en yüksek ortalamanın özyeterlilik $(4,120)$ alt boyutuna, en düşük ortalamaların sırasıyla iyimserlik $(3,633)$, psikolojik dayanıklılık $(3,801)$ ve umut $(3,902)$ alt boyutlarına ait olduğu tespit edilmiştir. Değişkenlerin minimum, maksimum, standart sapma ve ortalama değerleri incelenmiş ve sonuçlar aşağıda Tablo 2'de sunulmuştur.
Tablo 2. Pozitif Psikolojik Sermaye ve Yenilikçi Davranışa Ait Bazı Tanımlayıcı İstatistikler

\begin{tabular}{lccccc}
\hline & $\mathrm{N}$ & Ort. & Std. Sapma & Min. & Maks. \\
\hline Pozitif Psikolojik & 125 & 3,864 & 0,325 & 2 & 4 \\
Sermaye & 125 & 4,120 & 0,609 & 1 & 4 \\
Özyeterlilik & 125 & 3,902 & 0,540 & 2 & 4 \\
Umut & 125 & 3,801 & 0,500 & 2 & 4 \\
Psikolojik & 125 & 3,633 & 0,423 & 2 & 4 \\
Dayanıkl1lik & 125 & 4,093 & 0,750 & 1 & 5 \\
İyimserlik & & & & & \\
Yenilikçi Davranış & & & & & \\
\hline
\end{tabular}

\subsection{Geçerlilik ve Güvenilirlik Analizi}

Genel olarak, faktör analizinin yapılacağı ölçekte yer alacak madde sayısı 5 katından az olmamak üzere 200-250 civarındaki bir örneklemin çoğu sosyal bilimler araştırmaları 
için yeterli olabileceği söylenebilir (Gürbüz vd., 2017: 318319). Bu araştırma kapsamında örneklem sayısı 125 olduğu için faktör analizi uygulanmamıştır. Yüz geçerliliği, aracın ölçmeyi hedeflediği şeyi ölçüp ölçemeyeceğinin uzman bakış1 ile değerlendirilmesidir ve araştırma için yüz geçerliliği yapılarak uzman görüşü alınmıştır.

Gerçekleştirilen güvenilirlik analizi neticesinde Cronbach's Alpha katsayıları incelenmiştir. Bu değerin en az 0,60 olması gerekmektedir (Gürbüz vd., 2017). Her iki ölçekten sağlanan katsayılar incelendiğinde, güvenilirlik seviyelerinin iyi seviyede olduğu belirlenmiştir. Ancak umut alt boyutu Cronbach's Alpha değerinin düşük çıkması sebebiyle umut 4 ifadesi çıkarılarak yeniden test edilmiş ve 0,657 değeri elde edilmiştir. $\mathrm{Bu}$ çıkarılan ifade analizler dâhilinde kullanılmamıştır. Tüm boyutlara ait güvenilirlik analizi sonuçları Tablo 3'te sunulmuştur.

Tablo 3. Güvenilirlik Analizi

\begin{tabular}{lcc}
\hline Ölçek & İfade Sayısı & Cronbach's Alpha \\
\hline Pozitif Psikolojik Sermaye & & \\
\hline Özyeterlilik & 6 & 0,852 \\
Umut & 6 & 0,657 \\
Psikolojik Dayanıklılık & 6 & 0,696 \\
İyimserlik & 6 & 0,685 \\
Yenilikçi Davranış & 6 & 0,903 \\
\hline
\end{tabular}

\subsection{Araştırma Değişkenleri Arasındaki Korelasyon} ve Regresyon Analizine İlişkin Bulgular

Değişkenlere ait alt boyutlar arasındaki ilişkilere yer veren Pearson Korelasyon analizi bulguları Tablo 4'de belirtilmiştir. $\mathrm{Bu}$ sonuçlara göre, özyeterlilik ve yenilikçi davranış boyutu $(\mathrm{r}=-0,045, \mathrm{p}>0.01)$, umut ve yenilikçi davranış boyutu $(\mathrm{r}=$ 0,005, p>0.01) arasında anlamlı bir ilişki bulunamamıştır. Bununla birlikte, iyimserlik ve yenilikçi davranış boyutu $(\mathrm{r}=0,044, \mathrm{p}>0.01)$ arasında istatistiksel açıdan anlamlı bir ilişki saptanmamıştır. Fakat psikolojik dayanıklılık ve yenilikçi davranış boyutu $(\mathrm{r}=0,245, \mathrm{p}<0.01)$ arasında anlamlı bir ilişkinin varlığından söz edilebilir.

Tablo 4. Değişkenler Arası Korelasyon Analizi

\begin{tabular}{lccccc}
\hline & $(1)$ & $(2)$ & $(3)$ & (4) & (5) \\
\hline (1) Yenilikçi Davranış & 1 & & & & \\
(2) Özyeterlilik &,- 045 & 1 & & & \\
(3) Umut &,- 005 &, $266^{* *}$ & 1 & & \\
(4) Psikolojik Dayanıklılık &, $245^{* *}$ &, $191^{*}$ &, $260^{* *}$ & 1 & \\
(5) İyimserlik &, 044 &, 040 &, 173 &, 174 & 1 \\
\hline **Korelâsyonlar 0.01 düzeyinde anlamlı, *Korelâsyonlar 0.05 & \\
düzeyinde anlamlı & & & & \\
\hline
\end{tabular}

Pozitif psikolojik sermaye alt boyutlarından sadece psikolojik dayanıklılığın yenilikçi davranışı anlamlı bir şekilde etkilediği saptanmış ve analiz sonucu Tablo 5'te sunulmuştur. Gerçekleştirilen analizler neticesinde H3 hipotezi kabul edilirken, H1, H2 ve H4 hipotezleri reddedilmiştir.

Tablo 5. Değişkenler Arası Regresyon Analizi

\begin{tabular}{lcccc}
\hline Model & $\begin{array}{c}\text { Std. Edilmiş } \\
\text { Beta }\end{array}$ & $\mathrm{t}$ & Anlamlılık & $\begin{array}{c}\text { Modele İlişkin } \\
\text { Değerler }\end{array}$ \\
\hline Psikolojik & & & & $\mathrm{R}=0,568$ \\
Dayanıkl11k &, 271 & 2,291 & 0,004 & $\begin{array}{c}\mathrm{R}^{2}=0,070 \\
\mathrm{~F}=2,269 \\
\end{array}$ \\
& & & Anlam $=0,001$ \\
\hline
\end{tabular}

Bağımlı değişken: Yenilikçi Davranış

\section{Sonuç Ve Öneriler}

$\mathrm{Bu}$ araştırmanın amacı, pozitif psikolojik sermaye boyutlarının (özyeterlilik, umut, psikolojik dayanıklılık ve iyimserlik) yenilikçi davranış üzerindeki etkilerinin tespit etmektir. Bu kapsamda, çalışma amacına ulaşabilmek için, Bandırma ilçesi banka sektöründe çalışanlar üzerinde 125 veri ile analizler gerçekleştirilmiştir. $\mathrm{Bu}$ araştırmada, banka çalışanlarının pozitif psikolojik sermaye düzeyleri ve yenilikçi davranışları ele alınmıştır.

Araştırma kapsamına yer alan hipotezler regresyon analizi ile ölçülmüştür. Araştırma bulgularında pozitif psikolojik sermaye alt boyutlarından psikolojik dayanıklılığın yenilikçi davranışı anlamlı bir şekilde etkilediği sonucuna ulaşılmıştır. Literatürde yer alan araştırmalar incelendiğinde (Bandura, 1997; Avey vd., 2010; Luthans vd., 2004; Whelan vd., 2011) özyeterlilik, umut, psikolojik dayanıklılık ve iyimserlik düzeyleri yüksek olduğunda çalışanların gönüllü ve istekli bir şekilde görev aldıkları işletmelerin yeni fikirlerini iş birimlerine ya da işletmelerine uygulanabilmesi ve bu durumu kabul edip benimsenmesi çok daha kolay olabilmektedir. Farklı bir ifade ile psikolojik sermayesi yüksek düzeyde olan çalışanların ortaya çıkabilecek yenilikçi davranışlarıyla iş yaşantılarına kolay adaptasyon sağlayabileceklerdir. Örgüt içerisinde çalışanların pozitif psikolojik sermayelerinin ve yenilikçi davranışın kendi performanslarına etkisi ve bu sebeple örgütlerin verimli ve etkili olmasında etkili olabileceği yöneticiler tarafindan göz önünde bulundurulmalıdır.

Araştırma sonuçları arasında pozitif psikolojik sermaye alt boyutları özyeterlilik, umut ve iyimserliğin yenilikçi davranış üzerinde etkisi saptanmamıştır. Burada çalışanların özyeterlilik konusunda özellikle kendilerine olan güven eksikliklerinden dolayı yenilikleri kabullenme konusunda problem yaşadıkları sonucu çıkarılabilir. Güven eksikliği yaşayan çalışanların işlerinde başarılı olması, hedef ve amaçları konusunda umutsuzluğa kapıldıkları ve gelecek için işlerinin kendi açılarından belirsiz bir hal alacağı ile alakalı pozitif düşünememekte ve bundan ötürü yenilikleri kabullenmeyip yenilikçi davranışlar sergileyemedikleri söylenebilir.

Yazın taraması yapıldığında, pozitif psikolojik sermaye ve alt boyutları ve yenilikçi davranış ile ilgili ayrı ayrı pek çok çalışmanın yer aldığı belirlenmiştir. Bu çalışmalar arasında finansal sektör üzerinde yapılan araştırma sayısının çok az sayıda olduğu aksine eğitim, sağlık ve havacılık sektöründe daha fazla araştırma yapıldığ 1 belirlenmiş ve bu nedenden dolayı banka personelleri üzerinde araştırma gerçekleştirilmiştir. Ayrıca ulusal ve uluslararası alanda pozitif psikolojik sermaye ve yenilikçi davranış değişkenlerinin bir arada kullanıldığı çok fazla araştırmaya rastlanılmamıştır.

Diğer araştırmalarda yer aldığı gibi, bu araştırmanın da bazı sınırlılıklarından bahsedilmektedir. Belirlenmiş olan kurumda sınırlı sayıda katılım ile yapılmış olan bu araştırmanın sonuçlarını genelleştirmek zorlaşmaktadır. $\mathrm{Bu}$ konuda okuyucuların bunu göz önünde bulundurmaları gerekmektedir. $\mathrm{Bu}$ açıdan bakıldığında, gerçekleştirilecek araştırmaların daha fazla kurum ve sektörü barındırması, daha geniş katılımcının yer alması ve araştırmanın uzun dönem zamanı içinde yapılması çalışma sonuçlarının genelleştirilmesi bakımından önem arz etmektedir. Ayrıca, bu araştırma Balıkesir Bandırma ilçesindeki anket yapılan banka şubeleriyle ile 
sınırlandırılmıștır. Gelecek araştırmalar için Balıkesir Körfez ilçelerinde (Akçay, Altınoluk, Ayvalık, Burhaniye, Edremit, Güre, İvrindi vd.) yer alan bankalar üzerinde çalışmanın gerçekleştirilmesi daha kapsamlı olmasını sağlayacaktır.

\section{Kaynakça}

Abbas, M., \& Raja, U. (2015). Impat of Psychological Capital on Innovative Performance and Job Stress. Canadian Journal of Administrative Sciences, 32, 128-135.

Akçay, V. H. (2012). Pozitif İş Sermayenin İş Tatmini ile İlişkisi. Kahramanmaraş Sütçü İmam Üniversitesi İktisadi ve İdari Bilimler Fakültesi Dergisi, 2(1), 123-140.

Akkoç, İ., Turunç, Ö., \& Çalışkan, A. (2011). Gelişim Kültürü ve Lider Desteğinin Yenilikçi Davranış ve İş Performansına Etkisi: İş-Aile Çatışmasının Aracılık Rolü. The Journal of Industrial Relations and Human Resources, 13(4), 83-114.

Akman, Y., \& Korkut, F. (1993). Umut Ölçeği Üzerine Bir Çalışma. Hacettepe Üniversitesi Eğitim Fakültesi Dergisi, 9, 193-202.

Altunışık R., Coşkun R., Bayraktaroğlu S. \& Yıldırım E. (2010). Sosyal Bilimlerde Araştırma Yöntemleri SPSS Uygulamal, Sakarya, Sakarya Yayıncılık.

Avey, J. B., \& Nimnicht, J. L. (2010). Two Field Studies Examining the Association Between Positive Psychological Capital and Employee Performance. Leadership \& Organization Development Journal, 31(5), 384-401.

Avey, J. B., Luthans, F., \& Youssef, C. M. (2009). The Additive Value of Positive Psychological Capital in Predicting Work Attitudes and Behaviors. Journal of Managrment, 36(2), 430-452.

Avey, J. B., Reichard, R. J., Luthans, F., \& Mhatre, K. H. (2011). Meta-Analysis of the Impact of Positive Psychological Capital on Employee Attitudes, Behaviors, and Performance, Published in Human Resource Development Quartely, 22(2), 127-152.

Avolio, B. J., \& Luthans, F. (2006). The High Impact Leader: Moments Matter in Accelerating Authentic Leadeship Development. New York: Mcgraw-Hill.

Aydoğan, E., \& Kara, A. U. (2015). Pozitif Psikolojik Sermaye ile Bireysel Performans İlişkisi: Türkiye Tarım Kredi Kooperatifi Merkez Birliği Örneği. Üçüncü Sektör Sosyal Ekonomi, 50(1), 68-91.

Bandura, A. (1977). Self-Efficacy: Toward a Unifying Theory of Behavioral Change. Psychological Review, 84(2), 191215.

Bandura, A. (1986). Social Foundations of Thought and Action. Washington: Prentice Hall.

Basım, H. N., Korkmazyürek, H., \& Tokat, A. O. (2008). Çalışanların Özyeterlilik Algılamasının Yenilikçilik ve Risk Alma Üzerine Etkisi: Kamu Sektöründe Bir Araştırma. Selçuk Üniversitesi Sosyal Bilimler Enstitüsü Dergisi, 19, 121-130.
Beğenirbaş, M., \& Turgut, E. (2016). Psikolojik sermayenin Çalışanların Yenilikçi Davranışlarına ve Performanslarına Etkileri: Savunma Sektöründe Bir Araştırma. Dokuz Eylül Üniversitesi İktisadi ve İdari Bilimler Fakültesi Dergisi, 31(1), 57-93.

Carmeli, A., Meitar, R., \& Weisberg, J. (2006). SelfLeadership Skills and Abilities. International Journal of Management Power, 27(1), 75-90.

Chou, C. Y., Huang, C. H., \& Lin, T. A. (2018). Organizational İntellectual Capital And İts Relation To Frontline Service Employee İnnovative Behavior: Consumer Value Co-Creation Behavior As A Moderator. Service Business. 12(4), 663-684.

Clercq, D. D., Dimov, D., \& Belausteguigoitia, I. (2016). Perceptions of Adverse Work Conditions and Innovative Behavior: The Buffering Roles of Relational Resources. Entrepreneurship Theory and Practice, 40(3), 515-542.

Çalışkan, A., Akkoç, İ., \& Turunç, Ö. (2011). Örgütsel Performansın Artırılmasında Motivasyonel Davranışların Rolü: Yenilikçilik ve Girişimciliğin Aracılık Rolü. Süleyman Demirel Üniversitesi İktisadi ve İdari Bilimler Fakültesi Dergisi, 16(3), 363-401.

Çelik, M. (2012). Konaklama İşletmelerinde Alg1lanan Örgütsel Adaletin Yenilikçi Davranışa Etkisinde Kariyer Memnuniyetinin Aracılık Etkisi. "İş, Güç" Endüstri İlişkileri ve Insan Kaynakları Dergisi, 14(2), 101-122.

Çetin, F., \& Basım, H. N. (2012). Örgütsel Psikolojik Sermaye: Bir Ölçek. Amme Iddaresi Dergisi, 45(1), 121137.

Damanpour, F., \& Evan, W. M. (1984). Organizational Innovation and Performance: The Problem of "Organizational Lag. Administrative Science Quarterly, 29(3), 392-409.

Dess, G. G., \& Lumpkin, G. T. (2005). The Role of Entrepreneurial Orientation in Stimulating Effective Corporate Entrepreneurship. Academy of Management Perspectives, 19(1), 147-156.

Drucker, P. (1985). The Discipline of the Innovator. Harvard Business Review, 63(3), 67-72.

Engelen, A., Weinekötter, L., Saeed, S., \& Enke, S. (2018). The Effect Of Corporate Support Programs On Employees' Innovative Behavior: A Cross-Cultural Study. Journal Prod. Innovation Management, 35(2), 230-253.

Erdem, B., Gökdeniz, A., \& Met, Ö. (2011). Yenilikçilik ve İşletme Performansı İlişkisi: Antalya'da Etkinlik Gösteren 5 Yıldızlı Otel İşletmeleri Örneği. Dokuz Eylül Üniversitesi Íktisadi ve İdari Bilimler Fakültesi Dergisi, 26(2), 77-112.

Erkmen, T., \& Esen, E. (2013). Psikolojik Sermaye Ölçeğinin Geçerlilik ve Güvenilirlik Çalışması. Öneri Dergisi, 10(39), 23-30.

Erkuş, A. \& Afacan Findıklı, M. (2013), Psikolojik Sermayenin İş Tatmini, İş Performansı ve İşten Ayrılma Niyeti Üzerindeki Etkisine Yönelik Bir Araştırma, Ístanbul Üniversitesi Işletme Fakültesi Dergisi, 42(2), 302-318. 
Ertürk, A. (2012). Linking Psychological Empowerment to Innovation Capability: Investigating the. International Journal of Business and Social Science, 14(3), 153-165.

Frank J. (1968). The Role of Hopein Psychotherapy, International Journal of Psychiatry. 5(5), 383-395.

Grobler, A., \& Joubert, Y. T. (2018). Psychological Capital: Convertgent and Discriminant Validity of a Reconfigured Measure, South African Journal of Economic and Management Sciences 21(1), 1-14.

Gürbüz, S., \& Şahin, F. (2017). Sosyal Bilimlerde Araştırma Yöntemleri, Ankara, Seçkin Yayıncılık.

Harms, P. D., \& Luthans, F. (2012). Measuring Implicit Psychological Constructs in Organizational Behavior: An Example Using Psychological Capital. Journal of Organizational Behaviour, 33(4), 589-594.

Hayton, J. C., \& Kelley, D. J. (2006). A Competency-Based Framework for Promoting Corporate Entrepreneurship. Human Resource Management, 45(3), 407-427.

Hur, W. M., Rhee, S. Y., \& Ahn, K. H. (2016). Positive Pysychological Capital and Emotional Labor in Korea: The Job Demands-Resources Approach. The International Journal of Human Resource Management, 27(5), 477-500.

Hrnjic, A., Velic, A. P., Djidelija, I., \& Jahic, H. (2018). Innovative Behavior And Employee Job Satisfaction In Telecommunications Sector. Economic Review Journal Of Economics And Business, 16(1), 19-30.

Jafri, H. (2012). Psychological Capital and Innovative Behaviour: An Empirical Study on Apparel Fashion Industry, The Journal Contemporary, 6(1), 42-52.

Jung, H. S., \& Yoon, H. H. (2015). The Impact of Employees Positive Psychological Capital on Job Satisfaction and Organizational Citizenship Behaviors in the Hotal. International Journal of Contemporary Hospitality Management, 27(6), 1135-1156.

Jensen, S. M., \& Luthans, F. (2006). Relationship Between Entrepreneurs' Psychological Capital and their Authentic Leadership. Journal of Managerial Issues, 18(2), 254-273.

Kanter, R. M. (1988). When a Thousand Flowers Bloom: Structural, Collective, and Social Conditions for Innovation in Organization. Research in Organizational Behaviour, 10, 169-211.

Karacaoğlu, K., \& İnce, F. (2013). Pozitif Örgütsel Davranışın Örgütsel Sinizm Üzerindeki Etkileri: Kayseri İlindeki İmaalt Sanayi İşletmelerinde Bir Uygulama. Süleyman Demirel Üniversitesi İktisadi ve İdari Bilimler Fakültesi Dergisi, 18(1), 181-202.

Karadal, H., \& Özsungur, F. (2017). Hizmet İnovasyon Davranışı ile Psikolojik Sermaye ve Etik Liderlik İlişkisinin İncelenmesi: Adana Örneği. Uluslararası Yönetim İktisat ve İsletme Dergisi, ICMEB17 Özel Sayısı, 663-672.

Keleş, H. N. (2011). Pozitif Psikolojik Sermaye: Tanımı, Bileşenleri ve Örgüt Yönetimine Etkileri. Organizasyon ve Yönetim Bilimleri Dergisi, 3(2), 343-350.

Kim, T., Karatepe, O. M., \& Lee, G. (2017). Psychologica Contract Breach and Service Innovation Behavior:
Psychological Capital as a Mediator. Service Business, 12(2), 305-329.

Kızanlıklı, M., \& Çöp, S. (2017). Otel İşletmesi Çalışanlarında Pozitif Psikolojik Sermaye ile İş Performansı Algısı. Journal of Tourism and Gastronomy Studies, 5(3), 268287.

Lewis, S. (2011). Positive Psychology at Work: How Positive Leadership and Appreciative Inquiry Create Inspiring Organizations. United Kingdom: Wiley-Blackwell.

Lumpkin, G. T., \& Dess, G. G. (2001). Linking Two Dimensions of Entrepreneurial Orientation to Firm Performance: The Moderating Role of Environment and Industry Life Cycle. Journal Of Business Venturing, 16(5), 429-451.

Luthans, F. (2002a). Positive Organizational behavior: Developing and Managing Psychological Strengths. Academy of Management Perspectives, 16(1), 57-72.

Luthans, F. (2002b). The Need for and Meaning of Positive Organizational behavior. Journal of Organizational Behaviour, 23, 695-706.

Luthans, F. (2010). Organizational Behaviour: An EvidenceBased Approach. New York: McGraw -Hill.

Luthans, F., Avey, J. B., Avolio, B. J., \& Peterson, S. J. (2010). The Development and Resulting Performance Impact of Positive Psycholohgical Capital. Human Resource Development Quarterly, 21(1), 41-67.

Luthans, F., Avolio, B. J., Avey, J. B., \& Norman, S. M. (2007). Psychological Capital: Measurement and Relationship with Performance and Job Satisfaction. Personnel Psychology, 60(3), 541-572.

Luthans, F., Avolio, B. J., Walumbwa, F. O., \& Weixing, L. (2005). The Psychological Capital of Chinese Workers: Exploring the Relationship with Performance. Management and Organization Rwview, 1(2), 249-271.

Luthans, F., Norman, S. M., Avolio, B. J., \& Avey, J. B. (2008). The Mediating Role of Psychological Capital in The Supportive Organizational Climate-Employee Performance Relationship. Journal of Organizational Behavior, 29, 219-238.

Luthans, F., Youssef, C. M., \& Avolio, B. J. (2006). Psychological Capital: Developing the Human Competitive Edge. New York: Oxford University Press.

Luthans, F., \& Youssef, C. M. (2004). Human, Social, and Now Positive Psychological Capital Management: Investing in People for Competittive Advantage. Management Department Faculty Publications, 33(2), 143-160.

Luthar, S. S., Cicchetti, D., \& Becker, B. (2000). The Construct of Resilience: A Critical Evaluation and Guidelines for Future Work. Child Development, 71(3), 543-562.

Maddi, S. R. (2006). The Journal Of Positive Psychology: Dedicated to Furthering Research and Promoting Good Practise. Building and Integrated Positive Psychology, 1(4), 226-229. 
Masten, A. S. (2001). Ordinary Magic: Resilience Processes in Development. American Psychologist, 56(3), 227-238.

Ocak, M., Güler, M., \& Basım, N. (2016). Psikolojik Sermayenin Örgütsel Bağlılık ve İş Tatmini Tutumları Üzerine Etkisi: Bosnalı Öğretmenler Üzerine Bir Araştırma. Çankırı Karatekin Üniversitesi İktisadi ve İdari Bilimler Fakültesi Dergisi, 6(1), 113-130.

Özkan, G. V. (2017). Çalışanların özyeterlilik Düzeyinin Yaratıcı ve Yenilikçi İş Davranışlarına Etkisi: Farklı Sektörlerde Faaliyet Gösteren Örgütler Üzerinden Karşılaştırmalı Bir Değerlendirme. Journal of Yasar University, 12(47), 181-191.

Rego, P. Lopes, M. P., \& Nascimento, J. L. (2016). Authentic Leadership and Organizational Commitment: The Mediating Role of Positive Psychological Capital. Journal of Industrial Engineering and Management, 9(1), 129151.

Robbins, S. P. (2001). Organizational Behaviour. New Jersey: Prentice Hall.

Sanders, K., Moorkamp, M., Torka, N., Groenveld, S., \& Groeneveld, C. (2010). How to Support Innovative behaviour? The Role Of LMX and Satisfaction With HrR Practices. Technology and Investment, 1, 59-68.

Scott, S. G., \& Bruce, R. A. (1994). Determinants of Innovative Behavior: A Path Model of Individual Innovation in the Workplace. Academy of Management Journal, 37(3), 580-607.

Schuckert, M., Kim, T. T., Paek, S., \& Lee, G. (2017), Motivate to Innovate How Authentic and Transformational Leaders Influence Employees' Psychological Capital and Service İnnovation Behavior. International Journal of Contemporary Hospitality Management, 30(2), 776-796.

Seligman, M. E. (1998). Learned Optimisim. New York: Pocket Books.

Seligman, M. E. (2002). Authentic Happiness. New York: Free Press.

Seligman, M. E., \& Csikszentmihalyi, M. (2000). Positive Psychology: an Introduction. Republished with permission from the American Psychologist, 55(1), 5-14.

Melhem, S. M., Zeffane, A., \& Albaity, M. (2018). Determinants Of Employees' İnnovative Behavior. International Journal of Contemporary Hospitality Management, 30(3), 1601-1620.

Stajkovic, A. D., \& Luthans, F. (1998). Social Cognitive Theory and Self-Efficacy: Goin Beyond Traditional Motivational and Behavioral Approaches. Organizational Dynamics, 26(4), 62-74.

Sweetman, D., Luthans, F., Avey, J. B., \& Luthans, B. C. (2011). Relationship between Positive Psychological Capital and Creative Performance. Canadian Journal of Adminstrative Sciences, 28(1), 4-13.

Turkmenoglu, M. A. (2018). Hope and Patience as Coping of Food Managers in the Face of Challanges: The Turkish Case. Int. J. Work Organisations and Emotion, 9(3), 209223.
Turgut, E., \& Beğenirbaş, M. (2013). Çalışanların Yenilikçi Davranışları Üzerinde Sosyal Sermaye ve Yenilikçi İklimin Rolü: Sağlı Sektöründe Bir Araştırma. KHO Bilim Dergisi, 23(2), 101-124.

Unsworth, K. L., Brown, H., \& McGuire, L. (2000). Employee Innovation: The Roles of Idea Generation and Idea Implementation. In the Annual Conference of the Society for Industrial and Organizational Psychology. New Oeleans.

West, M., \& Farr, J. (1989). Innovation at Work: Psychological perspectives. Social Behavior, 4(1), 15-30.

Whelan, E., Parise, S., Valk, J. D., \& Aalbers, R. (2011). Creating Employee Networks that Deliver Open Innovation. Management Review, 53(1), 36-45.

Woodman, R. W., Sawyer, J. E., \& Griffin, R. W. (1993). Toward a Theory of Organizational Creativity. Academy of Management Review, 18(2), 293-321.

Wu, C. H., Parker, S. K., \& Jong, J. P. (2014). Need for Cognition as an Antecedent of Individual Innovation Behavior. Journal of Management, 40(6), 1511-1534.

Yeşil, S., Yetiş, E., \& Tellli, S. (2016). Psikolojik Sermaye ve Çalışanlar Üzerinde Etkisi: Banka Sektöründe Bir Alan Çalışması. International Journal of Academic Value Studies, 2(2), 25-40.

Yıldız, H., \& Örücü, E. (2016). Sağlık Sektörü Çalışanlarının Pozitif Psikolojik Sermaye Düzeylerinin Belirlenmesine Yönelik Bir Araştırma. Yönetim ve Ekonomi Araştırmaları Dergisi, 14(1), 269-285.

Yuan, F., \& Woddman, R. W. (2010). Innovative Behavior in the Workplace: The Role of Performance and Image Outcome Expectations. Academy of Management Journal, 53(2), 323-342.

Zhou, J. (2003). When the Presence of Creative Coworkers is Related to Creativity: Role of Supervisor Close Monitoning, Developmental Feedcabk, and Creative Personality. Journal of Applied Psychology, 88(3), 413422.

Ziyae, B., Mobaraki, M. H., \& Saeediyoun, M. (2015). The Effect of Pyschological Capital on Innovation in Information Technology. Journal of Global Entrepreneurshşp Research, 5(8), 1-12. 